А.С. Жанбосинова*

Борис Чирков и Лев Залин: к биографии руководства НКВД Казахской $\mathrm{CCP}^{* *}$

DOI: $10.31518 / 2618-9100-2019-1-7$

УДК 9-93/94

Выходные данные для цитирования:

Жанбосинова А.С. Борис Чирков и Лев Залин: к биографии руководства НКВД Казахской ССР // Исторический курьер. 2019. № 1 (3). Статья 7. URL: http://istkurier.ru/data/2019/ ISTKURIER-2019-1-07.pdf

\section{A.S. Zhanbosinova*}

\section{Boris Chirkov and Lev Zalin: on the biography of the NKVD leaders of the Kazakh SSR}

\author{
DOI: 10.31518/2618-9100-2019-1-7
}

How to cite:

Zhanbosinova A.S. Boris Chirkov and Lev Zalin: on the biography of the NKVD leaders of the Kazakh SSR // Historical Courier, 2019, \# 1 (3). Article 7. [Available online:] http://istkurier.ru/data/2019/ ISTKURIER-2019-1-07.pdf

Abstract: The article is devoted to the problem of political repression in Kazakhstan during the years of the NKVD mass operations in 1937-1938. The history of political repression consists of two parts: the former includes the perpetrators of terror, the latter - its victims. While the history of terror's victims is represented by a significant set of research publications, the history of its perpetrators, with regards to the personal history of the NKVD staff, has not been studies adequately. When writing the article, the author relied on the biographical documents of the NKVD officers and the archival and investigative files of the repressed. For the first time, informative materials are introduced into the scientific circulation, revealing the pages of the biographies of the NKVD leaders of the Kazakh Soviet Socialist Republic, who in 1938-1940 turned out to be under investigation for alleged violation of socialist legality. The author tried to uncover the procedural algorithm of the investigative measures, to bring the facts of violations committed by the investigators of the NKVD. The content of the cited documents testifies to the fabrication of investigative cases by the KGB, the falsification of the materials of the investigation, as well as the use of physical violence and moral and psychological humiliation against the arrested. All the operational and investigative activities of the NKVD were subject to the orders of 1937-1938, instructions and circular documents, where targets for mass operations were prescribed, including regional statistics. The latter gave the investigative process the character of socialist competition, an analogue of the Stakhanov movement. The study shows the Great Terror in the interweaving of life trajectories of punitive bodies' employees and victims of terror.

Keywords: Boris Chirkov; Lev Zalin; political repression; East Kazakhstan; the NKVD; physical violence; falsification.

The article has been received by the editor on 15.01.2019.

Full text of the article in Russian and references in English are available below.

\footnotetext{
* Жанбосинова Альбина Советовна, д-р ист. наук, профессор кафедры истории Казахстана ВосточноКазахстанского государственного университета им. С. Аманжолова (Усть-Каменогорск, Казахстан), е-таil: sovetuk@rambler.ru

Zhanbosinova Albina Sovetovna, Doctor of Historical Sciences, Professor of the Department of History of Kazakhstan, S. Amanzholov East-Kazakhstan State University (Ust-Kamenogorsk, Republic of Kazakhstan), e-mail: sovetuk@rambler.ru

** Статья написана в рамках Проекта КН МОН РК ИРН: АР05130870 «Память о жертвах политических репрессий (1920-1950-е г2.) и ее фиксаџия в сакральном ландшафте Казахстана (на примере Восточного Казахстана)».

The article is written in the framework of the project of the Control Committee of the Ministry of Education and Science of the Republic of Kazakhstan IRN: AP05130870 "Memory of the victims of political repression (1920-1950's) and its fixation in the sacral landscape of Kazakhstan (on the example of East Kazakhstan) ".
} 
Аннотация: Статья посвящена проблеме политических репрессий в Казахстане в годы массовых операций НКВД 1937-1938 гг. Впервые в научный оборот вводятся информативные материалы, раскрывающие страницы биографии руководителей НКВД Казахской ССР, оказавшихся в 1938-1940 гг. под следствием по обвинению в нарушении «социалистической законности». Если история жертв политических репрессий представлена значительным комплексом исследовательских публикаций, то персональная история сотрудников НКВД не получила должного освещения. При написании статьи, автор опирался на анкетнобиографические документы сотрудников НКВД и архивно-следственные дела репрессированных. Впервые в научный оборот вводятся информативные материалы, раскрывающие страницы биографии руководителей НКВД Казахской ССР, оказавшихся в 19381940 гг. под следствием по обвинению в нарушении социалистической законности. Автор попыталась раскрыть процессуальный алгоритм следственных мероприятий, привести факты допущенных следователями НКВД правонарушений. Содержание цитируемых документов свидетельствует о фабрикации чекистами следственных дел, фальсификации материалов следствия, а также применении физического насилия и морально-психологического унижения в отношении арестованных. Вся оперативно-следственная деятельность НКВД подчинялась содержанию приказов НКВД 1937-1938 гг. и инструктивно-циркулярным документам, где прописывались целеполагающие установки по массовым операциям, включая статистические показатели по регионам. Последние придали следственному процессу характер социалистического соревнования, аналог стахановского движения. Проведенное исследование показывает Большой террор в переплетении жизненных траекторий сотрудников карательных органов и жертв террора.

Ключевые слова: Борис Чирков; Лев Залин; политические репрессии; Восточный Казахстан; НКВД; физическое насилие; фальсификация.

История политических репрессий имеет множество граней. Вся палитра исследовательских подходов продемонстрирована в разноплановой и обширной литературе, от пионера репрессивной тематики Роберта Конквеста ${ }^{1}$ до автора концептуально нового подхода в оценке Большого террора Марка Юнге ${ }^{2}$, исследователя истории деятельности органов госбезопасности НКВД Владимира Хаустова ${ }^{3}$ и многих других.

Одним из новых и перспективных направлений в изучении государственного террора в СССР является исследовательская деятельность, направленная на возвращение лиц, как анонимным жертвам репрессий, так и сотрудникам карательных органов, главным проводникам репрессивной политики сталинского государства. Большую ценность для исследований такого рода имеют личные дела чекистов и архивно-следственные дела репрессированных, которые выступают в качестве источника информации о биографии жертвы, представляют процессуальный алгоритм следствия, порой содержат личные документы, фотографии и письма. Работа с архивными материалами Специального государственного архива Министерства внутренних дел Республики Казахстан (далее СГА МВД РК) и архива Департамента внутренних дел Восточно-Казахстанской области (далее ДВД ВКО) позволила выявить комплекс документов, раскрывающих страницы Большого террора в освещении его непосредственных участников и жертв. Данная статья призвана внести коррективы в биографии двух высших руководителей органов НКВД Казахской ССР периода Большого террора: Бориса Николаевича Чиркова и Льва Борисовича Залина, а также

\footnotetext{
${ }^{1}$ Конквест Р. Большой террор. Рига: Ракстниекс, 1991. 413 с.

${ }^{2}$ Юнге М., Бордюгов Г., Биннер Р. Вертикаль большого террора. М.: «Новый хронограф», 2008,784 с.; Юнге М., Биннер Р. Как Террор стал «Большим». Секретный приказ № 00447 и технология его исполнения. М.: АИРО-ХХ, 2003. 352 c.

${ }^{3}$ Хаустов В., Самуэльсон Л. Сталин, НКВД и репрессии 1936-1938 гг. М.: РОССПЭН, 2010. 432 с.
} 
выявить общее и особенное в осуществлении массовых операций НКВД 1937-1938 гг. в Казахстане.

Борис Чирков родился в 1906 г. в городе Глазов Удмуртской $\mathrm{ACCP}^{4}$. Некоторые сведения его биографии содержатся в письме начальника отдела кадров НКВД Казахской ССР на имя Л.П. Берии от 28 декабря 1938 г., сообщавшего, что «Чирков происходит из семьи землевладельца, его мать по происхождению дворянка. В октябре 1938 г. в Таганроге был арестован отец жены Чиркова - Ружицкий Иван Ануфриевич, в прошлом польский дворянин, титулярный советник, чиновник особых поручений Министерства финансов. За сокрытие социального происхождения и службу в колчаковской армии, был исключен из ВКП(б) в 1937 г., в которой состоял с 1921 г. И. Ружицкий был осужден по первой категории» 5 .

В период колчаковщины семья Чирковых проживала в Сибири, где отец служил счетоводом. В автобиографии Чирков сообщал, что его отец, Чирков Николай Николаевич, в 1912-1913 гг. переехал из Глазова Удмуртской АССР в Омск. Он служил счетно-конторским работником у разных частных лиц фирм, в частности был счетным работником Амурского, Иртышского и Обского пароходств, работал в банках. Н.Н. Чирков имел свое хозяйство, надворные постройки, водяную мельницу с применением наемной рабочей силы. В Омске отец Чиркова до революции работал в парфюмерном магазине, Земской управе и Сибирском торговом банке. В этом банке Николай Чирков продолжал работать и в период колчаковщины. После ликвидации колчаковщины Н.Н. Чирков трудился в советских и хозяйственных организациях, в том числе в Государственном банке, умер в 1924 г. Мать Б.Н. Чиркова - Александра Сергеевна Чиркова - учительствовала в Омске. В семье было четыре сына, включая Бориса Чиркова, а также две дочери.

В 1919 г. Б. Чирков закончил шестиклассный курс гимназии, откуда трижды исключался за «громкое поведение», но благодаря связям отца возвращался к учебе. В 1919 г. Борис проживал в Омске, где в 1919 г. был арестован контрразведкой Колчака. Поводом к аресту послужило распространение им большевистской литературы. Одновременно с ним были арестованы члены Сибирской подпольной коммунистической организации, с которыми Чирков был знаком. За день до освобождения Омска частями Красной армии Чирков был освобожден. Там же в Омске в 1920 г. Борис Чирков вступил в ВЛКСМ (в первый раз в декабре 1919 г. он не был принят из-за болезни). В мае 1920 г. Борис ушел добровольцем в РККА, в Первую Сибирскую кавалерийскую дивизию. В РККА он служил вестовым в кавэскадроне, одновременно учился на курсах Всевобуча в Омске, которые окончил в декабре 1920 г. С декабря 1920 г. Чирков - сотрудник политотдела дивизии, затем до июня 1922 г. красноармеец, секретарь военкома, врид военкома эскадрона связи. В мае 1922 г. он возвратился в Омск и губкомом ВЛКСМ был направлен на работу в распоряжение Особого Отдела Западно-Сибирского военного округа.

С июня 1922 по сентябрь 1923 г. Чирков служит начальником розыска Особого отдела ГПУ ЗСВО, с сентября 1923 г. - уполномоченным Особого отдела 29-й стрелковой дивизии. После этого его жизненные пути надолго разминулись с Сибирью - с сентября 1924 г. он является сотрудником Смоленского губотдела ОГПУ, в том числе - помощником уполномоченного по Ярцевскому уезду и уполномоченным по Рославльскому уезду и округу. Возможно, переводу на запад Чирков был обязан обвинению в подделке с корыстной целью денежных документов и присвоении денег, принадлежащих Особому отделению 29-й дивизии.

\footnotetext{
${ }^{4}$ Биография Б.Н. Чиркова составлена на основе разрозненных архивных данных из документов СГА МВД РК, ДВД ВКО. Автобиография, собственноручно написанная Чирковым, отсутствует в личном деле. Кроме того, используются сведения из справочников: Петров Н.В., Скоркин К.В. Кто руководил НКВД. 1934-1941. Справочник. М.: Звенья, 1999; Жуков А.Н. «Кадровый состав органов государственной безопасности СССР. 1935-1939» [Электронный pecypc]. URL: http://nkvd.memo.ru/. Автор также благодарит А.Г. Теплякова за предоставленные сведения.

${ }^{5}$ СГА МВД РК Ф. 2. Оп. 1. Д. 21. Л. 7.
} 
С января 1930 г. Чирков служит помощником начальника и начальником 2-го отделения ИНФО ПП ОГПУ по Западной области. В июле 1932 г. он возвращается в Сибирь в качестве начальника Алданского оперсектора ОГПУ, где, по данным 2 Отдела ГУГБ НКВД СССР, принимал участие вместе с бывшим начальником ГПУ Якутской АССР К.К. Зединым и начальниками отделов регионального управления города Алдана в подготовке и отправке из Алдана двух пудов золота на имя Ягоды ${ }^{6}$ В конце апреля 1934 г. Чирков получает свое первое крупное назначение в качестве заместителя начальника Якутского облотдела ГПУ. С ноября 1934 г. по сентябрь 1936 г. Чирков занимает пост заместителя начальника УНКВД по Якутской АССР, ему присваивается специальное звание «ст. лейтенант ГБ» (2.3.1936), что соответствует армейскому майору. С сентября 1936 г. он ненадолго возглавил Владимирский ГО НКВД, после чего с 8 февраля 1937 г. по январь 1939 г. занял пост начальника УНКВД по Восточно-Казахстанской области. В этой должности он был награжден в декабре 1937 г. орденом Красной Звезды, избирался депутатом Верховного Совета Казахской ССР. Чирков был председателем тройки УНКВД по ВКО (приказ № 00447) и Особой тройки («национальные операции», действовала с сентября по ноябрь 1938 г.). 3 января 1939 г. Чиркову было присвоено специальное звание «капитан ГБ», с этого дня и по 17 декабря 1939 г. он занимал пост заместителя наркома внутренних дел Казахской ССР.

В период Большого террора на территории Восточного Казахстана в рамках реализации приказов НКВД №o 00447, 00485, 00593 и др., были обнаружены «очаги контрреволюционной деятельности», «активными участниками» которых оказалось множество руководителей области разного уровня. В числе арестованных был Свердлов секретарь Восточно-Казахстанского обкома, Курицын - первый секретарь городской парторганизации, Гаврилов - секретарь обкома комсомола ВКО, персональное обсуждение которых проходило на заседаниях бюро горкома и обкома партии. Показательно, что Б. Чирков, руководствуясь профессиональным опытом или политической интуицией, практиковал изъятие из горкома и обкома партии стенограмм своих выступлений, якобы для корректировки, и потом их просто не возвращал, вероятно, не желал оставлять компрометирующие документы о своей персоне 7 .

Однако тесные отношения Б. Чиркова с партийными руководителями не помешали ему в 1939 г. подвергнуть избиению Курицына - первого секретаря Петропавловской городской парторганизации. Для получения признательных показаний Курицына подвергли методу непрерывного допроса без сна. Метод заключался в том, чтобы вызвать арестованного на допрос в 23-24.00 часа и держать на допросе до утра. Так как по правилам тюрьмы днем спать запрещено, то арестованный оставался без сна. Такой метод допроса применялся до полного истощения 8 .

Известное «Дело церковников» в Восточном Казахстане, где в общем списке арестованных самому старшему было 84 года, а младшему - 65 лет, было сфальсифицировано следующим образом. Со слов заключенного Черемисина, следователь всех арестованных по этому делу возил в горы, где в одной из землянок заставил оборудовать молитвенный дом, надеть ризы и взять в руки кадило, после этого их сфотографировал и приложил фотокарточку как вещественное доказательство 9 .

17 ноября 1938 г. было принято Постановление СНК СССР и ЦК ВКП (б) «Об арестах, прокурорском надзоре и ведении следствия», которое положило начало кампании по дисциплинированию НКВД и возвращению «органов» в рамки прежней компетенции ${ }^{10}$. В рамках этой кампании была проведена широкая «чистка» органов госбезопасности, в ходе которой из НКВД только за 1939 г. было уволено 7372 сотрудника, а за конец 1938-1939 гг.

\footnotetext{
${ }^{6}$ Там же. Д. 22. Л. 3-4, 8.

${ }^{7}$ СГА МВД РК Ф. 2. ОП. 1. Д. 21. Л. 9.

${ }^{8}$ Там же. Д. 2077. Л. 63.

9 Там же. Л. 65.

${ }^{10}$ Органы государственной безопасности СССР накануне Великой Отечественной войны. Сборник документов. (ноябрь 1938 г. - декабрь 1940 г.). М.; СПб., 1995. Т. 1.708 с.
} 
было арестовано по обвинению в совершении должностных преступлений 1364 чекиста. Чирков также оказался под прицелом кампании как один из нарушителей соцзаконности.

В 1939 г. по распоряжению Л.П. Берии проводилось работа по изучению материалов обвинения народного комиссара внутренних дел Казахской ССР майора ГБ С.Н. Бурдакова и заместителя наркома НКВД КазССР капитана ГБ Б.Н. Чиркова в связях с врагами народа и необеспечении борьбы по разоблачению врагов в бытность Бурдакова председателем Спецколлегии Верховного Суда Казахской ССР, а Чиркова - начальником УНКВД по ВКО. Однако первая попытка наказания Чиркова окончилась ничем: комиссия пришла к выводу, что обвинения, выдвинутые против С. Бурдакова и Б. Чиркова, не подтвердились.

Более неприятным для Чиркова стало расследование фактов нарушения социалистической законности, предпринятое в 1940 г. В адрес Чиркова было выдвинуто обвинение в необоснованных арестах советских граждан, в применении мер физического насилия и фальсификации следственных дел. Приводимые документы изобилуют статистическими данными о деятельности тройки УНКВД, возглавляемой Б. Чирковым, приводятся данные о количестве незаконно арестованных и расстрелянных. Так, например, при исполнении решения тройки УНКВД по ВКО был ошибочно расстрелян Григорий Казанцев, подлежавший заключению в лагерь на 10 лет, вместо Михаила Казанцева, приговоренного к расстрелу. Вместо наказания виновных чекистов, Б. Чирков произвел исправления в протоколе тройки, внеся задним числом расстрельный приговор в отношении Григория Казанцева. Аналогичные исправления были произведены в отношении Баталова, Нури, Карменова также ошибочно расстрелянных. Под непосредственным контролем Б. Чиркова было сфальсифицировано дело, в результате чего был произведен арест и расстрел членов Чингистауской партийной организации ${ }^{11}$. УНКВД по ВКО не был исключением, аналогичные явления случались сплошь и рядом, как например, в Кустанайской области был случай, когда чекисты привели в исполнение приговор тройки над человеком, который не был приговорен к ВМН, работники НКВД спутали имя и отчество. В документах проверки деятельности подразделений НКВД областного и районного уровня фиксировалось, что порой тройка рассматривала дела с одним только актом о том, что обвиняемый отказался от показаний, причем этот документ составлялся самими работниками райотделений НКВД ${ }^{12}$.

Чирков любил возить арестованных на место расстрела, оказывать на них психологическое угнетающее воздействие, после чего производил допросы ${ }^{13}$. В материалах дела по расследованию деяний Б. Чиркова обнаружены свидетельства выживших. Так, например, Борисов, арестованный в 1938 г. и освобожденный из-под стражи в 1939 г., рассказал: «8 мая 1938 года привели меня на допрос к Начальнику УНКВД Чиркову, который требовал от меня признания в участии контрреволюционной организации. Я отказался. Тогда он стал меня сам избивать: бил кулаком в висок головы, пока не пошла ручьем из носа кровь и запух правый глаз, отдохнул и снова начал меня бить ремнем по голове и сапогом в живот, по коленям ног. Избиение продолжалось до тех пор, пока я не написал заявление под диктовку и не подписал протокол ложных признаний». Бывший сотрудник УНКВД Олесницкий во время допроса показал, что: «вообще-то арестованные боялись Чиркова как огня, так как он, обходя кабинеты, отпускал крепкие затрещины арестованным». Арестованного Борисова привели в кабинет Чиркова днем. Чирков, закрыв занавески и сняв портупею, избил ею Борисова, после чего тот заявил, что больше не будет скрывать правды и даст подробные показания, что он и сделал ${ }^{14}$. Физическое воздействие

\footnotetext{
${ }^{11}$ СГА МВД РК Ф. 2. Оп. 1. Д. 2077. Л. 48.

12 Там же. Д. 22. Л. 23.

13 Подобные способы воздействия на арестованных находили свое крайнее выражение в так называемом «допросе на яме», который производился непосредственно во время расстрела осужденных у общей могилы. О расправах периода Большого террора см. подробнее: Тепляков А. Сибирь: Процедура исполнения смертных приговоров в 1920-1930-х годах // Голоса Сибири: литературный альманах. Вып. 4 / сост. М. Кушникова, В. Тогулев. Кемерово: Кузбассвузиздат, 2006. С. 213-277.

${ }^{14}$ Архив ДВД ВКО. Ф.19. Оп. 2. Д. 2801.
} 
применялось в бытность Чиркова начальником УНКВД по ВКО также по отношению к Эдуарду Сигурту, бывшему красноармейцу и красному партизану, который был обвинен по статье 58-10 УК РСФСР. Во время допроса он подвергался систематическому избиению, стоянию на ногах (выстойке) в течение 15 суток, в камеру его доставили в синяках и опухшими ногами ${ }^{15}$.

Мат, угрозы и ругань являлись обыденным явлением следственного процесса. Практически все, кому удалось выжить и написать жалобу, сообщали, что Б. Чирков проявлял невероятную грубость и жестокость по отношению к арестованным, помимо матерщины, угроз и ругани, он допускал такие вещи, как харканье в рот арестованного, прижигание папиросой кончика носа. Сам Чирков в объяснении своих методов следствия заявил: «Меры физического воздействия в УНКВД ВКО применялись чаще всего мною лично. Делал это не из любви к “искусству”, а потому что сознавал необходимость таких мер, я не хотел втягивать в это аппарат» ${ }^{16}$

Один из бывших сотрудников УГБ УНКВД по ВКО, подчиненный Чиркова, так описывал в письме секретарю ЦК ВКП(б) А.А. Жданову допросы под руководством Чиркова: «Вопервых, как мне, а также всем молодым комсомольцам приходилось работать при разгроме троцкистско-бухаринского охвостья, национал-фашистов, а также при уничтожении шпионов и диверсантов, то Чирков руководил следующим путем, сразу после ареста, арестованного ставили на ноги без воды и сна, чтобы он рассказал свои преступления, арестованные доходили без сознания, приходилось отливать водой и подносить подписать протокол то, что там было написано, все страницы. Как Чирков, также Комар и Михайлов давали [нам на допрос] арестованного и говорили, чтобы до утра рассказал все свои преступления, арестованный не рассказывает, тогда его ставили на ноги, не давали ему пить и спать, до тех пор, пока он не начнет сходить с ума, тогда давали ему подписывать протокол заранее написанный, все страницы» ${ }^{17}$. Нередко в одной комнате находилось несколько арестованных, стоящих лицом к стене (лицом к стене ставили специально, чтобы отсутствие пространственного видения вызывало головокружение), их ноги натекли кровью, все они смотрели друг на друга и плакали. Следователи били арестованных кулаком в живот и заставляли делать приседания, держа руки вверх, до тех пор, пока они сами не предлагали: давайте подпишу протокол. Следователи «по установке» писали в протоколах, что хотели и вписывали фамилии списками по восемь-пятнадцать человек, чтобы потом тех арестовать ${ }^{18}$.

Очевидно, что расследование 1940 г. окончилось для Чиркова относительно благополучно: его, как и многих «проштрафившихся» чекистов, отправили на работу в ГУЛАГ. С декабря 1939 г. по апрель 1940 г. он занимал должность начальника управления Темниковского лагеря НКВД для военнопленных финской войны, до июля 1942 г. начальника Управления Джезказганского ИТЛ и Джезказганского медеплавильного и горного комбината НКВД, до января 1943 г. - начальника Управления Тырны-Аузского ИТЛ и горно-медного комбината НКВД (Кабардино-Балкарская АССР), добывавшего вольфрам и молибден. Лишь в январе 1943 г. Чирков оказался в действующей армии в звании подполковника. Служил в 10-й гвардейской воздушно-десантной дивизии: комбат, затем заместитель командира дивизии по тылу. С января 1945 г. Чирков по линии НКВД начинает активно участвовать в реализации советского атомного проекта. С сентября 1946 г. по октябрь 1953 г. он является начальником комбината № 6 (2-е Главное управление при Совете Министров СССР) - первенца советской атомной промышленности, уже в октябре 1949 г. ему присваивается звание Героя Социалистического Труда «за исключительные заслуги перед государством при выполнении специального задания» (вместе с такими учёными, как Н.А. Доллежаль, Я.Б. Зельдович, И.В. Курчатов, Ю.Б. Харитон, К.И. Щелкин).

\footnotetext{
${ }^{15}$ СГА МВД РК Ф.2. Оп. 1. Д. 2077. Л. 63.

${ }^{16}$ Из материалов архивно-следственных дел Архива ДВД ВКО.

${ }^{17}$ СГА МВД РК. Ф. 2. Оп. 1. Д. 21. Л. 50-55.

18 Там же. Л. 50-55.
} 
Тем не менее, новые заслуги не смогли перечеркнуть преступлений, совершенных Чирковым в 1937-1938 гг. Результатом проведенного расследования по Б.Н. Чиркову стал приказ МВД СССР за №1233 от 15 декабря 1952 г. об увольнении его из органов МВД за нарушение социалистической законности, по фактам, дискредитирующим звание начсостава органов МВД. В 1953 г. после тяжёлого инфаркта Чирков был переведён начальником печально известного предприятия п/я 28 (урановый горно-металлургический комбинат министерства среднего машиностроения СССР, он же Восточный горно-обогатительный комбинат в г. Жёлтые Воды Днепропетровской области). С 1957 г. Чирков на пенсии, в этом же году его исключили из КПСС, а в январе 1959 г. лишили звания Героя Социалистического Труда и всех наград «за нарушения в прошлом социалистической законности». Скончался Б.Н. Чирков в Москве в 1978 г.

В 1937 - марте 1938 гг. НКВД Казахской ССР возглавлял Лев Борисович Залин (с января 1935 г. по 1937 г. он являлся начальником УНКВД по Казахской АССР). В июне 1938 г. Залин был арестован и расстрелян в 1940 г. Наркома обвинили во многих преступных деяниях, в том числе и извращении следственной работы. Выяснилось, что в стенах НКВД творился произвол, а «оперативные мероприятия, которые должны были быть направлены на разгром организованной контрреволюции, наносили удар по случайному элементу, не имеющему связи с контрреволюцией» ${ }^{19}$.

Несмотря на обилие нормативной и циркулярной документации, сотрудники УНКВД Казахстана в своем большинстве руководствовались установками, звучавшими на республиканских совещаниях и на личных встречах с Л.Б. Залиным. Так, например, на одном из совещаний он сделал замечание областным руководителям: «У вас в области нет националистической низовки, нужно вскрыть в ближайшее время» ${ }^{20}$. Выслушав руководство, начальники областных управлений «летели» обратно в область вскрывать националистическую «низовку». На следующих встречах звучало обвинение в том, что не вскрыто повстанчество среди русского казачества, необходимо «вскрыть» и «дать выход за кордон» ${ }^{21}$. В свою очередь начальники областных управлений устраивали соревнования, кто больше арестует, хвалясь между собой, у меня столько-то арестованных, по первой категории через тройку, пропустил такое количество. Начальники областных управлений в свою очередь разжигали соревнования между районами, ругали тех начальников райотделений, кто отставал по количеству арестованных.

В результате в районах аресты зачастую производились без материалов оперативного учета и даже без учета социальных данных. Поэтому нередко в колхозах этими арестами задевались колхозники, «социально близкие» Советской власти. Последние репрессировались как «контрреволюционный элемент» в общей массе арестованных.

Своеобразие Восточного Казахстана заключалось в том, что практически всех арестованных чекисты причисляли к повстанческим организациям. Указанная особенность объяснялась массовыми крестьянскими восстаниями в годы насильственной коллективизации и пограничным положением области. В водоворот массовых крестьянских волнений, охвативших Самарский, Шемонаихинский, Катон-Карагайский районы Семипалатинского округа, оказалась вовлечена огромная масса крестьянского населения ${ }^{22}$. В соответствии с приказом № 00447 от 30 июля 1937 г. одним из главных объектов репрессий являлась категория «бывших», участники повстанческих движений. Метод, изобретенный районными отделами НКВД Восточно-Казахстанской области, был удобен безграничным расширением численности повстанческой организации. Я. Бергман бывший инспектор при Наркомвнудел КазССР, сообщал, что следователи райотделений готовы были

\footnotetext{
${ }^{19}$ СГА МВД РК. Ф. 2. Оп. 1. Д. 22. Л. 23.

20 Там же.

${ }^{21}$ Там же.

${ }^{22}$ Абылхожин Ж. Очерки социально-экономической истории Казахстана. ХХ век. Алматы: Университет «Туран», 1997. 360 с.
} 
и дальше арестовывать, но уставали от необходимости записывать показания. Арестованный мог говорить, что он вздумает, лишь бы употреблялись слова, «член повстанческой организации» $^{23}$. Чекисты также полагали, что, когда начались аресты в районах, весь «активный контрреволюционный элемент» из деревни немедленно выехал, укрылся в городе на производстве, что якобы обнаружилось в ходе агентурных донесений, процесса наклейки фотографий на гражданские паспорта в отделениях милиции.

Все следственные группы подчинялись непосредственно Народному комиссару внутренних дел Казахской ССР Залину. Он контролировал и направлял ведение следствия, знакомился с результатами. Именно под контролем Залина вначале 1937 г. началась разработка одного из наиболее «громких» дел казахстанских чекистов - дела Анатолия Израилевича Кельмансона, работавшего в г. Риддере с 1928 по 1930 гг. В 1936 г. он работал в качестве председателя государственного планирования Казахской АССР. Установка, данная следственной группе, предполагала связать А. Кельмансона с Риддером, т.к. вскрытие дела было намечено как ликвидация вредительской организации, созданной агентами Уркварта, среди специалистов цветной промышленности. ${ }^{24}$

Следственная группа, направленная в Риддер, получила задание провести следствие и собрать фактический материал по вредительским актам и «вскрыть» так называемую «вредительскую низовку». Все арестованные по этому делу сосредотачивались в Алма-Ате, где под руководством Л. Залина велись допросы обвиняемых. Дело А. Кельмансона неожиданно для следствия приобрело троцкистскую окраску, благодаря показаниям эсера Вицмана о том, что существовал блок эсеров и троцкистов, где от имени троцкистов связь якобы осуществлял сам А. Кельмансон. Нечеловеческое насилие, применяемое следователями, вынудило А. Кельмансона дать показания на Г.Л. Пятакова.

Отметим, что Георгий Пятаков, бывший заместитель Народного комиссара тяжелой промышленности СССР, проходил по делу «Параллельного антисоветского троцкистского центра» в качестве основного обвиняемого 25 . Он якобы завербовал А. Кельмансона и по его заданию тот создавал троцкистские вредительские организации на предприятиях цветной металлургии, в том числе и в Риддере.

Риддерский горотдел НКВД, в связи с приездом следственной группы из Алматы, стал производить массовые аресты рабочих, формируя из них «вредительскую низовку». Таким образом, оперативная работа по массовым операциям шла с двух сторон: руководящим составом занимались приезжие чекисты, местные отрабатывали риддерский пролетариат.

Вся вина за срыв пятилетних планов, за простой в строительстве промышленных объектов, за высокий травматизм была возложена на «вредителей» из «троцкистскозиновьевского блока»: «Данные, которыми располагает прокуратура республики, свидетельствуют о чрезвычайно высоком уровне травматизма на промышленных предприятиях Казахстана. Основной причиной этого является диверсионная и вредительская работа, проводимая врагами народа. Совершенно не случайно уровень промышленного травматизма, особенно значителен на предприятиях, где орудовали контрреволюционные троцкистские, бухаринские и национал-фашистские группы. [...] на предприятиях Риддерского комбината в 1936 году было несчастных случаев 1883, в том числе со смертельным исходом 3. В первом полугодии 1937 года несчастных случаев 809, в том числе со смертельным исходом 9. Эти данные следует считать совершенно преуменьшенными, если принять во внимание, что во всех указанных промышленных предприятиях в прошлом орудовали вредители, диверсанты и шпионы японо-германского фашизма, и они, естественно, всячески скрывали действительное наличие случаев травматизма и полного

\footnotetext{
${ }^{23}$ СГА МВД РК. Ф. 2. ОП. 1. Д. 22. Л. 4.

${ }^{24}$ Там же. Д. 216.

25 Лубянка. Сталин и Главное управление госбезопасности НКВД. Архив Сталина. Документы высших органов партийной и государственной власти. 1937-1938 / под ред. акад. А.Н. Яковлева; сост. В.Н. Хаустов, В.П. Наумов, Н.С. Плотникова. М.: МФД, 2004. 736 с.
} 
учета, не вели [...] пробравшиеся враги народа троцкисты, правые и национал-фашисты вели вредительскую работу, направленную на гибель рабочих (отравление их газами, обвал шахт и т. д.) $\rangle^{26}$.

Риддерский городской отдел НКВД начальство обвиняло в том, что при каждой поломке на предприятии, аварии производились аресты рабочих, которых судили за вредительство, что было «на руки троцкистско-зиновьевскому блоку», от которого отвлекалось подозрение в организации контрреволюционной вредительской деятельности ${ }^{27}$. Впрочем, самого Л. Залина и следственную группу, работавшую по делу А. Кельмансона, впоследствии обвинили в том, что они превратили расследование в узковедомственное локальное дело, не имевшее отношение к право-троцкистской организации в Казахстане и ее руководящему центру. Вероятно, предполагалось, что по результатам риддерского расследования в Казахстане удастся провести крупный судебный процесс по аналогии с Московскими процессами. Результаты следствия представили его как дело троцкистско-вредительской организации, охватившей лишь предприятия Риддера и Чимкента, созданной по инициативе А. Кельмансона и Г. Пятакова. В справке по комбинату «Алтайполиметалл» указывалось, что на данном предприятиями органами НКВД Казахстана ликвидирована диверсионновредительская группа во главе с главным инженером комбината В.Ф. Вебером, завербованным в троцкистскую диверсионно-вредительскую организацию А. Кельмансоном.

Среди индустриальных объектов тех лет Риддерский комбинат занимал видное положение. Но, как и по всей стране, здесь нарушалась техника безопасности, порой не выполнялись планы. Виновника долго искать не пришлось. В.Ф. Вебера обвинили в том, что составленные по его указанию рецепты создавали тяжелые условия плавки, и печи застывали, выходя из строя на длительные сроки, одновременно терялось большое количество металлов в шлаках. Он якобы сознательно привел проектно-сметное дело в состояние хаоса; сознательно удорожал стоимость проектирования; умышленно тормозил внедрение механизации строительных работ; умышленно давал заниженные нормы нагрузки на фундамент под здание строящегося завода; умышленно создавал условия для аварийности; саботировал мероприятия по технике безопасности, в результате среди 1600 рабочих было зарегистрировано 255 случаев травматизма и 247 случаев отравлений ${ }^{28}$.

Владимир Федорович Вебер, немец по национальности, беспартийный, работал главным инженером Риддерского комбината. В досье, собранном НКВД указывалось, что он находился в десятимесячной научной командировке в Америке, где и был завербован для шпионской деятельности в пользу Германии немецким инженером Хольманом. В 1933 г. завербован вторично А. Кельмансоном с целью проведения диверсионно-террористических акций. Лично им была создана диверсионная группа, завербованы начальники цехов Василий Иванович Агеев, Александр Александрович Марков, Павел Александрович Лаброс и другие руководители ${ }^{29}$.

В.И. Агеев работал начальником горного цеха Риддерского комбината, так же как и Вебер был в научной командировке заграницей, являясь для органов НКВД потенциальным шпионом, удобным для разработки. А.А. Марков работал главным механиком, относился к категории «бывших» - сын крупного заводчика. П.А. Ламброс работал начальником механического цеха, старый «уквартовский» служащий, был якобы «завербован» представителем Уркварта Лессингом с целью осуществления подрывных операций ${ }^{30}$.

Как следует из материалов следственного дела, все инженеры занимали высокие должности, позволявшие им проводить вредительские операции, срывать планы и задания правительства, что и старалась донести до своих читателей газета «Риддерский рабочий»:

\footnotetext{
${ }^{26}$ ГАВКО. Ф. 130п. Оп. 15. Д. 9. Л. 36-39.

${ }^{27}$ СГА МВД РК. Ф. 2. ОП. 1. Д. 22. Л. 7.

${ }^{28}$ ГАВКО. Ф. 130. ОП. 15. Д. 10. Л. 48.

${ }^{29}$ АП РК. Ф. 725. ОП. 2. Д. 43. Л. 58-63.

30 Там же. Л. 58-63.
} 
«Агенты германо-японо-троцкистских бандитов и шпионов, используя нашу беспечность и ротозейство проникли на руководящую работу в комбинате «Алтайполиметалл» (Вебер, Агеев, Марков и др.) и в течение долгого времени творили свое гнусное черное дело» ${ }^{31}$. В свою очередь в одной из областных газет вышла разгромная статья «В тресте “Большой Риддер" неблагополучно» ${ }^{32}$. Залин, выступая на І съезде КП(б)К, отметил, что «за последние годы неизмеримо вырос интерес японо-германского империализма к Казахстану. Известно, что троцкистский выродок А.Кельмансон и его сподручный на Риддере враг народа В. Вебер долгое время по заданию иностранных разведок занимались шпионажем. Поджигали и уничтожали склады, шахты, электростанции, совершали крушение поездов, затапливали шахты, вредили в финансировании МТС и совхозов». ${ }^{33}$ Залин, в отличие от Чиркова, не смог избежать скамьи подсудимых - его арестовали в июне 1938 г. по обвинению в участии в «заговоре в НКВД» и расстреляли в январе 1940 г. Однако главное обвинение в заговоре все же поддерживалось обвинением в нарушении соцзаконности.

Таким образом, введение в научный оборот новых источников из архивно-следственных и личных дел чекистов позволяет разобраться и понять мотивы поступков и поведения сотрудников карательных органов, осознать чудовищность «стахановских» методов следствия, где необходимость выполнения и перевыполнения планов превращала человека в карательную машину, не гнушавшуюся пытками, издевательствами и фальсификациями.

\section{Литература}

Абылхожин Ж. Очерки социально-экономической истории Казахстана. XX век. Алматы: Университет «Туран», 1997. 360 с.

Конквест Р. Большой террор. Пер. с англ. Л. Владимирова. Рига: Ракстниекс, 1991. 413 с.

Лубянка. Сталин и Главное управление госбезопасности НКВД. Архив Сталина. Документы высших органов партийной и государственной власти. 1937-1938. Под ред. акад. А.Н. Яковлева; сост. В.Н. Хаустов, В.П. Наумов, Н.С. Плотникова. М.: МФД, 2004. 736 с.

Органы государственной безопасности СССР накануне Великой Отечественной войны. Сборник документов. (ноябрь 1938 г. - декабрь 1940 г.). М.; СПб, 1995. Т. 1. 708 с.

Тепляков А. Сибирь: Процедура исполнения смертных приговоров в 1920-1930-х годах // Голоса Сибири: литературный альманах. Выпуск 4 / сост. М. Кушникова, В. Тогулев. Кемерово: Кузбассвузиздат, 2006. С. 213-277.

Хаустов В., Самуэльсон Л. Сталин, НКВД и репрессии 1936-1938 гг. Серия: История сталинизма. М.: РОССПЭН, 2010. 432 с.

Юнге М., Бордюгов Г., Биннер Р. Вертикаль большого террора. М.: «Новый хронограф», 2008, $784 \mathrm{c}$.

Юнге М., Биннер Р. Как Террор стал «Большим». Секретный приказ № 00447 и технология его исполнения. М.: АИРО-ХХ, 2003. 352 с.

\section{References}

Abylhozhin, Zh. Ocherki social'no-ehkonomicheskoj istorii Kazahstana. XX vek [Essays on the socio-economic history of Kazakhstan. XXth century]. Almaty: Universitet "Turan", 1997, 360 s.

Haustov, V., Samuehl'son, L. Stalin, NKVD i repressii 1936-1938 gg. [Stalin, the NKVD and the repression of 1936-1938. Series: History of Stalinism]. Seriya: Istoriya stalinizma. M.: ROSSPEN, 2010, $432 \mathrm{~s}$.

Junge, M., Bordyugov, G., Binner, R. Vertikal' bol'shogo terrora [The Vertical of Great Terror]. M.: "Novyj hronograf", 2008, 784 s.

\footnotetext{
${ }^{31}$ Риддерский рабочий. 1937. № 159. 15 июля.

${ }^{32}$ ГАВКО. Ф. 130. ОП. 15. Д. 10. Л. 53.

${ }^{33}$ Риддерский рабочий. 1937. № 161. 17 июля.
} 
Junge, M., Binner, R. Kak Terror stal "Bol'shim". Sekretnyj prikaz № 00447 i tekhnologiya ego ispolneniya. [How the Terror Became "Great". Secret Order № 00447 and the technology of its execution]. M.: AIRO-XX, 2003, $352 \mathrm{~s}$.

Konkvest, R. Bol'shoj terror [The Great Terror]. Per. s angl. L. Vladimirova. Riga.: Rakstnieks, $1991.413 \mathrm{~s}$.

Lubyanka. Stalin i Glavnoe upravlenie gosbezopasnosti NKVD. Arhiv Stalina. Dokumenty vysshih organov partijnoj i gosudarstvennoj vlasti. 1937-1938. [Lubyanka. Stalin and the General Directorate of State Security of the NKVD. Stalin's archive. Documents of the highest organs of party and state power. 1937-1938]. Pod red. akad. A.N. Jakovleva; sost. V.N. Haustov, V.P. Naumov, N.S. Plotnikova. M.: MFD, 2004. 736 s.

Organy gosudarstvennoj bezopasnosti SSSR nakanune Velikoj Otechestvennoj vojny [The bodies of state security of the USSR on the eve of World War II. Collection of documents. (November 1938 - December 1940)]. Sbornik dokumentov (noyabr' 1938 g. - dekabr' 1940 g.). M.: $\mathrm{SPb}, 1995 . \mathrm{T} .1 .708 \mathrm{~s}$.

Tepljakov A. Sibir': Procedura ispolnenija smertnyh prigovorov v 1920-1930-h godah [The procedure for the execution of death sentences in the 1920s-1930s] // Golosa Sibiri: literaturnyj al'manah. Vypusk 4 / sost. M. Kushnikova, V. Togulev. Kemerovo: Kuzbassvuzizdat, 2006. S. 213277.

Статья поступила в редакиџи 15.01.2019 2. 